\title{
Rancang Bangun Aplikasi Bus Trans Jogja Menggunakan Location Based Service Pada Perangkat Mobile Studi Kasus: (Bus Trans Jogja)
}

\author{
Prasetyo Budi Yulistanto ${ }^{*}$, Hariyady ${ }^{2}$, Aminudin $^{3}$ \\ 1,2,3Teknik Informatika/Universitas Muhammadiyah Malang \\ prasetyobudiyulistanto@gmail.com ${ }^{* 1}$, haryady@gmail.com², aminudin2008@gmail.com³
}

\begin{abstract}
Abstrak
Trans Jogja merupakan sistem transportasi bus yang melayani rute perjalanan seputar Kota Yogyakarta. Sistem ini mulai dioperasikan pada awal maret 2008 oleh Dinas Perhubungan Pemerintah Provinsi Daerah Istimewa Yogyakarta. Industri transportasi untuk saat ini mengalami perkembangan pesat terutama pelayanan tehadap penumpangnya. Namun pada penerapan sistem ini muncul permasalahan seringnya keterlambatan kedatangan armada bus serta penumpang tidak mengetahui dimana saja letak halte. Dari permasalahan diatas, peneliti membuat sebuah aplikasi yang dapat memudahkan para penumpang. Dengan perkembangan teknologi Location Based Service yang mampu memberikan layanan untuk mengetahui keberadaan dari suatu armada bus maupun halte. Aplikasi ini terintegrasi dengan layanan Google Maps untuk mengetahui antara pengguna dengan posisi armada bus dan halte. Untuk mengetahui posisi pengguna secara realtime dengan memanfaatkan teknologi Global Positioning System yang ada pada smartphone android.
\end{abstract}

Kata Kunci: Location Based Service, Google Maps, Global Positioning System

\begin{abstract}
Trans Jogja is a bus transportation system that serves the route around Yogyakarta city. This system began to be operated in early March 2008 by the Provincial Government Transportation Department of Yogyakarta Special Region. The transportation industry for now is experiencing rapid development especially the service to passengers. However, in the implementation of this system emerged the problem of frequent delay in the arrival of bus fleet and passengers do not know where the location of the bus stop. From the above problems, researchers create an application that can facilitate the passengers. With the development of Location Based Service technology that is able to provide services to know the existence of a bus fleet or bus stop. This app integrates with the Google Maps service to know between users with bus fleet positions and bus stops. To know the position of users in realtime by utilizing the technology of Global Positioning System that exist on android smartphone.
\end{abstract}

Keywords: Location Based Service, Google Maps, Global Positioning System

\section{Pendahuluan}

Trans Jogja merupakan salah satu alternatif transportasi massa yang beroperasi didalam Kota Yogyakarta sejak tahun 2008. Armada Trans Jogja yang dilengkapi dengan AC ini beroperasi setiap hari mulai pukul $05.30-21.30$ WIB dan melayani 6 rute khusus yang beberapa diantaranya tidak dilalui bus kota. Seperti layaknya Trans Jakarta, Trans Jogja juga memiliki halte yang tersebar di berbagai tempat. Sedangkan pembedanya adalah Trans Jogja tidak memiliki koridor khusus seperti Trans Jakarta, melainkan masih bercampur dengan kendaraan lainnya. Sistem yang menggunakan bus (berukuran sedang) ini menerapkan sistem tertutup, dalam arti penumpang tidak dapat memasuki bus tanpa melewati gerbang pemeriksaan, seperti juga Trans Jakarta. Selain itu, diterapkan sistem pembayaran yang berbeda-beda: sekali jalan, tiket berlangganan pelajar, dan tiket berlangganan umum. Ada tiga macam tiket yang dapat dibeli oleh penumpang, yaitu tiket sekali jalan (single trip), dan tiket umum berlangganan. Tiket ini berupa kartu pintar, bukan karcis bus biasa. Karcis akan diperiksa secara otomatis melalui suatu mesin yang akan membuka pintu secara otomatis. Penumpang dapat berganti bus tanpa harus membayar biaya tambahan, asalkan masih dalam satu tujuan[1]. 
Permasalahan yang seringkali muncul pada Bus Trans Jogja adalah tentang keterlambatan armada bus untuk datang ke setiap halte. Terkadang penumpang harus menunggu lama tanpa mengetahui keberadaan maupun kapan datangnya armada bus tersebut. Penumpang juga mengalami kebingungan dimana saja letak halte pemberhentian yang dilewati oleh armada bus. Untuk masalah tarif masih terdapat penumpang yang tidak mengetahui tata cara maupun metode pembayaran yang diterapkan. Terkadang bus datang dalam kondisi penuh sehingga pada halte tertentu membuat para penumpang banyak menunggu kedatangan armada bus berikutnya. Adanya permasalahan pada pelayanan Bus Trans Jogja, maka diperlukan sebuah aplikasi yang dapat membantu permasalahan tersebut dan meningkatkan mutu pelayanan terhadap para penumpang. Aplikasi yang diharapkan ini nantinya dapat membantu menyelesaikan permasalahan yang dialami para penumpang selama ini.

Berdasarkan masalah diatas, perlu dibuat aplikasi yang dapat menampilkan keberadaan kendaraan atau armada bus, menampilkan sebuah lokasi halte, menampilkan peta yang membantu penumpang dalam menentukan tujuan dan panduan bagi para penumpang tentang tata cara pembayaran maupun tiket isi ulang. Aplikasi ini mempermudah dalam pencarian kendaraan dengan mengirim SMS yang nantinya mendapat balasan dari alat GPS Tracker berupa kordinat url yang ditampilkan di maps. Pencarian lokasi halte didukung dengan fasilitas Google Maps API yang menunjukkan titik lokasi dari setiap halte Bus Trans Jogja yang ditampilkan berupa marker pada maps yang tersedia.

\section{Metode Penelitian}

Penelitian ini dilakukan dengan beberapa tahapan metode, antara lain:

\subsection{Studi Pustaka}

Studi pustaka merupakan pengumpulan literatur dan tahapan untuk memahami konsep LBS yang dikoneksikan pada android. Pemahaman dilihat dari buku, jurnal, serta internet.

\subsection{Analisa Kebutuhan}

Pada tahap analisa kebutuhan dilakukan terhadap Hardware dan Software yang dipakai dalam pembuatan aplikasi Bus Trans Jogja yang memanfaatkan LBS untuk diterapkan ke smartphone android.

\subsection{Perancangan Sistem}

Perancangan sistem merupakan fase tahapan setelah analisis proses dari berkembangnya sebuah sistem. Perancangan sistem disini berupa penggambaran atau perencanaan yang dapat difungsikan. Perancangan sistem menentukan proses mana saja yang harus sampai selesai. Tahap ini termasuk menerjemahkan beberapa perangkat lunak serta perangkat keras untuk dilakukan instalasi sesuai dengan rancangan awal sistem.

\subsection{Implementasi}

Implementasi merupakan proses penerapan dari hasil rancangan ke program yang telah dibuat kedalam sebuah aplikasi. Kegiatan implementasi dilakukan berpedoman pada dasar yang telah direncanakan dalam tahap perancangan.

\subsection{Pengujian}

Pada tahap ini aplikasi dikerjakan menggunakan Android Studio dan Bahasa Pemrograman Java. Google Maps API digunakan sebagai layanan untuk menampilkan maps, sedangkan untuk koneksi database menggunakan Bahasa Pemrograman PHP. Sistem manajemen database menggunakan MySQL. Aplikasi pengembang dalam Bahasa Pemrograman PHP dikerjakan menggunakan Sublime Text 2.

\section{Analisis dan Perancangan Sistem \\ 3.1 Arsitektur Sistem}

Pada gambar gambar dibawah ini akan dijelaskan secara singkat mengenai sistem yang akan dibuat, berikut adalah arsitektur dari program yang akan dirancang.

Berikut penjelasan arsitektur sistem berdasarkan Gambar 1:

1. Setiap bus akan di pasang GPS Tracker supaya dapat dideteksi keberadaannya.

2. GPS Tracker yang diterapkan untuk setiap bus nantinya akan mengirimkan SMS (Short Messages) kemudian akan dikirimkan balasan berupa link posisi keberadaan armada bus.

REPOSITOR, Vol. 2, No. 2, Februari 2020: 155-164 
3. Sms yang sudah dikirimkan tadi akan disimpan sementara di database.

4. Mobile akan menampilkan aplikasi dan menampilkan posisi dari bus serta diharuskan terkoneksi internet supaya posisi bus bisa dilihat secara realtime.
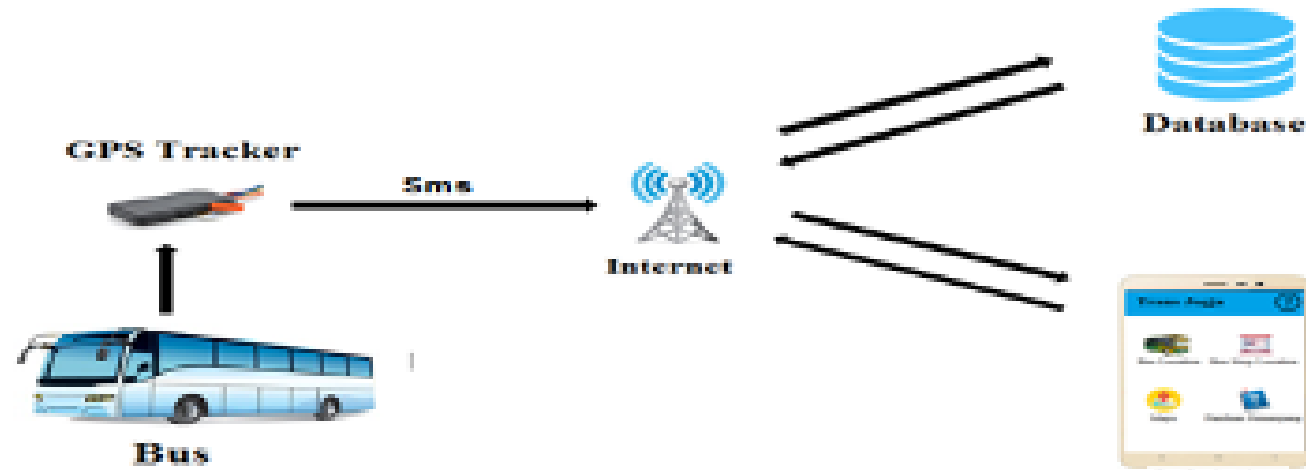

Gambar 1. Arsitektur Sistem

Pada Gambar 2 dijelaskan cara kerja dari aplikasi Bus Trans Jogja dengan mengambil contoh perjalanan dari Terminal Prambanan ke UGM.

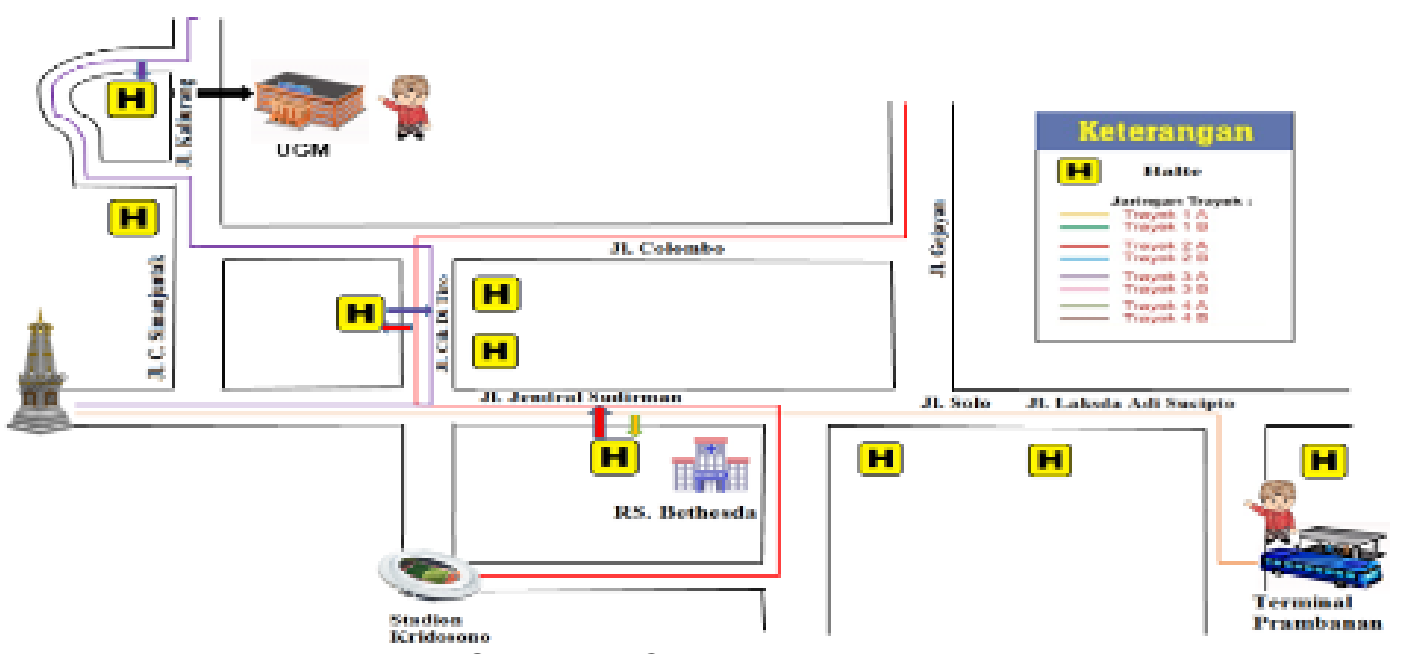

Gambar 2. Cara Kerja Aplikasi

Berikut penjelasan sistem kerja aplikasi menurut Gambar 2:

1. Seorang penumpang berada di Terminal Prambanan, kemudian dia ingin menuju ke kampus UGM.

2. Pertama - tama dia harus naik bus Trayek $1 \mathrm{~A}$ (garis warna orange) dan berhenti di Halte Jl. Jendral Sudirman.

3. Kemudian harus berganti bus Trayek 2A (garis warna merah) lalu berhenti di Halte JI. Cik Di Tiro.

4. Selanjutnya harus berganti bus Trayek 3B (garis warna ungu) serta berhenti di Halte Jl. Kaliurang terus berjalan menuju UGM.

\subsection{Usecase Diagram}

Menurut Martin Fowler (2005) Use Case adalah teknik untuk merekam persyaratan fungsional sebuah sistem. Use Case mendeskripsikan interaksi tipikal antara para pengguna sistem dengan sistem itu sendiri, dengan memberi sebuah narasi tentang bagaimana sistem tersebut digunakan [2].

Pada Gambar 3 menunjukkan use case diagram pada aplikasi Bus Trans Jogja. User dapat melakukan 5 interaksi, diantaranya: melihat menu utama, melihat menu bus location, melihat menu bus stop location, melihat menu maps dan melihat panduan penumpang. 


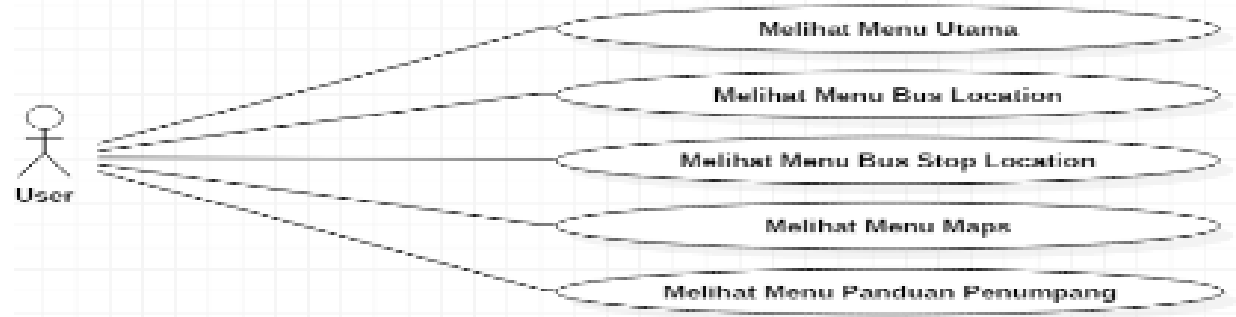

Gambar 3. Usecase Diagram

\subsection{Trans Jogja}

Lahirnya Bus Trans Jogja dimulai pada tahun 2004, dengan munculnya Studi Kelayakan Angkutan Eksekutif pada tahun Anggaran 2004 di Dinas Perhubungan Provinsi DIY. Pada saat itu sebutan untuk bus dimaksud adalah Bus Patas. Rencana implementasi pada tahun Anggaran 2005 tertunda karena kebutuhan studi kelayakan yang lebih komprehensif (mencakup analisis teknis, ekonomi, sosial-budaya, psikologis, dan wisata), sehingga pada tahun Anggaran 2005 Dinas Perhubungan Provinsi DIY telah mengadakan kegiatan-kegiatan yang berhubungan dengan persiapan operasional Bus Trans Jogja, antara lain : Studi kelayakan reformasi sistem transportasi angkutan umum perkotaan di Propinsi DIY, Sosialisasi operasional Bus Patas atau Bus Trans Jogja, Penyusunan draft MoU atau kerjasama pemerintah Propinsi DIY dengan operator Bus Patas atau Bus Trans Jogja dan Persiapan pembentukan badan pengelola Bus Patas dan penyusunan draft raperda badan pengelola Bus Patas[3].

\subsection{LBS (Location Based Service)}

Menurut Manav Singhal dan Anupam Shukla (2012) LBS adalah layanan informasi yang memanfatkan teknologi untuk mengetahui dan menampilkan posisi dari user maupun suatu kendaraan melalui sebuah teknologi positioning system. Teknologi tersebut dapat memudahkan maupun membantu user dalam mendapatkan suatu lokasi sesuai yang diinginkan [4].

\subsection{GPS (Global Positioning System)}

Menurut Ahmed El Rabbani Sistem kerja dari GPS adalah ketika sebuah satelit berada pada titik orbit bumi, maka akan dapat memberikan sinyal kiriman ke bumi yang kemudian ditangkap menggunakan alat penerima yang nantinya sinyal akan diubah menjadi sebuah informasi berupa titik posisi dari alat tersebut [5].

\subsection{GPS Tracker}

Menurut S. Tao, V. Manolopoulos, S. Rodriguez, dan A. Rusu (2012) GPS Tracker merupakan teknologi yang berfungsi untuk mengetahui posisi kendaraan secara real time. GPS tracker menggunakan teknologi GSM dan GPS. Pada sistem tracking kendaraan, teknologi GPS digunakan untuk memperoleh koordinat kendaraan yang dilengkapi perangkat GPS dan memperbaharui datanya secara real time [6].

\subsection{Android}

Menurut Kurniawan Teguh Martono \& Oky Dwi Nurhayati Android yaitu salah satu Operation system yang dimiliki oleh telepon pintar. Sistem yang mempunyai basis linux dirancang untuk perangkat pintar seperti telepon pintar memungkinkan perangkat lunak untuk dimodifikasikan secara bebas dan didistribusikan oleh pembuat perangkat operator nirkabel dan pengembang aplikasi. Pengembangan aplikasi yang memperluas fungsionalitas perangkat, umumnya ditulis dalam versi custom bahasa pemrograman Java [7].

\subsection{MySQL (My Structure Query Language)}

Menurut Madcoms MySQL merupakan perangkat lunak open source yang artinya perangkat lunak tersebut dapat digunakan dan dikembangkan oleh siapapun. Setiap orang dapat mengunduh aplikasi tersebut dari internet dan tanpa dikenakan biaya apapun. Dan jika kita mau kita bisa mempelajari source code dari MySQL dan memodifikasinya sesuai dengan kebutuhan kita [8]. 


\subsection{JSON (Java Script Object Notation)}

Menurut Chasseur, Craig., Li, Y. dan Patel, Jm (2013) JSON (Java Script Object Notation) adalah format pertukaran data yang bersifat ringan, disusun oleh Douglas Crockford. JSON dirancang untuk memudahkan pertukaran data pada situs dan merupakan perluasan dari fungsifungsi javascript [9].

\subsection{Google Maps API (Application Programming Interface)}

Menurut Gabriel Svennerberg (2010) Google Maps API adalah tool atau library dari Google untuk menampilkan peta digital di website, penggunaan Google Maps di website dapat melalui pemrograman [10].

\section{Hasil Penelitian dan Pembahasan}

\subsection{Implementasi}

Implementasi merupakan proses penerapan dari hasil rancangan ke program yang telah dibuat kedalam sebuah aplikasi. Kegiatan implementasi dilakukan berpedoman pada dasar yang telah direncanakan dalam tahap perancangan.

\subsubsection{Tampilan Menu Halaman Utama}

Menu halaman utama ini pada Gambar 4 menampilkan pilihan semua menu yang meliputi bus location, bus stop location, maps dan panduan penumpang. Tampilan menu halaman utama juga menampilkan gambar icon pada setiap menu.

\section{Trans Jogja}

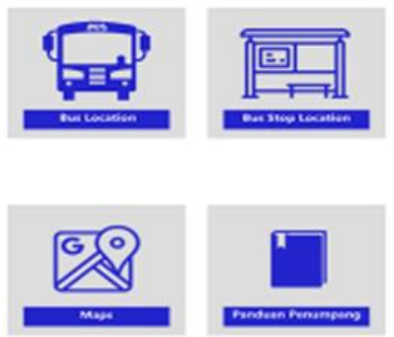

Gambar 4. Halaman Utama

\subsubsection{Tampilan Menu Bus Location}

Menu Bus Location Gambar 5 ini menampilkan posisi dari sebuah armada bus. Pada menu ini, bus ditampilkan dalam bentuk icon serta menampilkan posisi kita berada. Ketika pengguna menekan pada tombol Get Location Bus maka akan mengirimkan sebuah sms ke alat GPS Tracker, kemudian alat GPS Tracker mengirimkan pesan balik berupa url posisi dimana keberadaannya sekarang dan akan ditampilkan keberadaannya dalam bentuk icon.

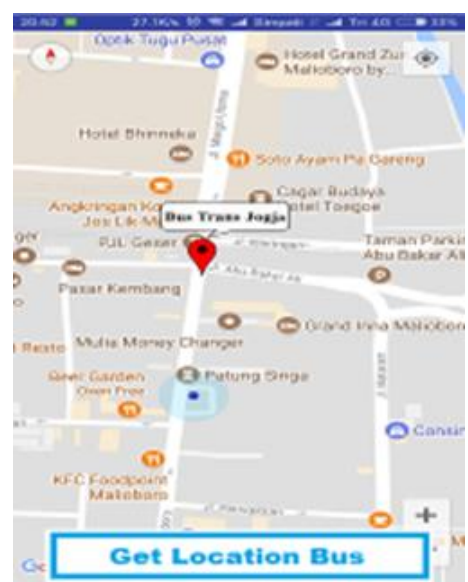

Gambar 5. Halaman Bus Location 


\subsubsection{Tampilan Menu Bus Stop Location}

Menu Bus Stop Location pada Gambar 6 menampilkan letak dari halte. Pada menu ini, halte ditampilkan dalam bentuk icon serta menampilkan posisi kita berada. Ketika pengguna menekan pada tombol icon yang dipilih akan muncul informasi. Untuk menuju lokasi yang diinginkan, user menekan icon maka akan ditampilkan rute yang dituju.

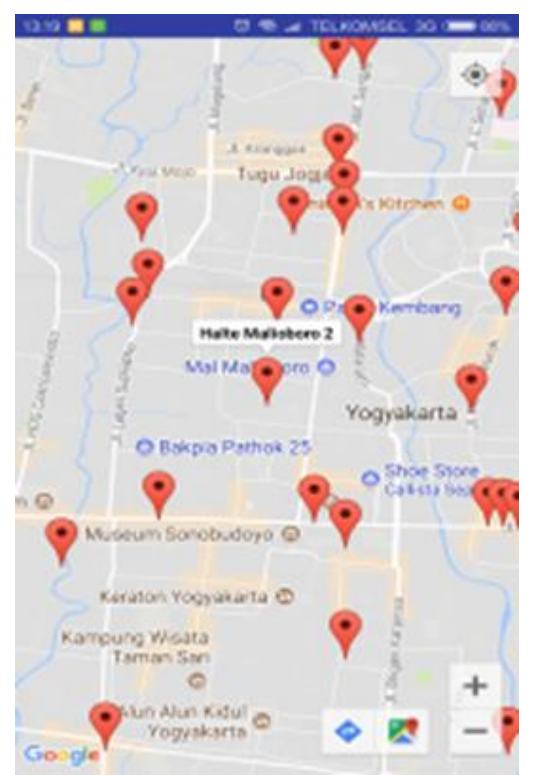

Gambar 6. Halaman Bus Stop Location

\subsubsection{Tampilan Menu Maps}

Gambar 7 menampilkan menu maps, yang merupakan menu tampilan keseluruhan wilayah terutama Yogyakarta. Pada menu ini, pengguna dapat melihat secara detail lokasi mana saja yang diinginkan melalui maps.

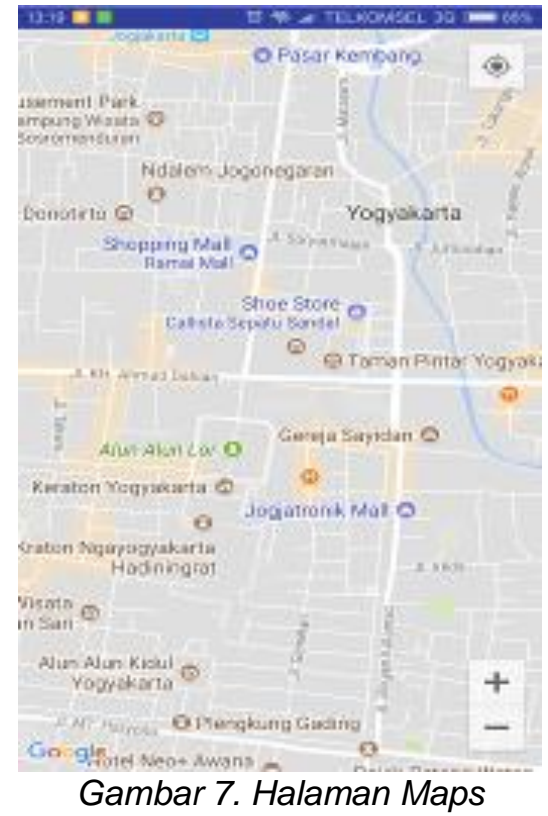

\subsubsection{Tampilan Menu Panduan Penumpang}

Menu panduan penumpang Gambar 8 merupakan menu yang menampilkan panduan dan diperuntukkan untuk penumpang. Pada menu tata cara naik Bus Trans Jogja diantaranya tentang penggunaan, transit, isi ulang dan kartu langganan rusak. 


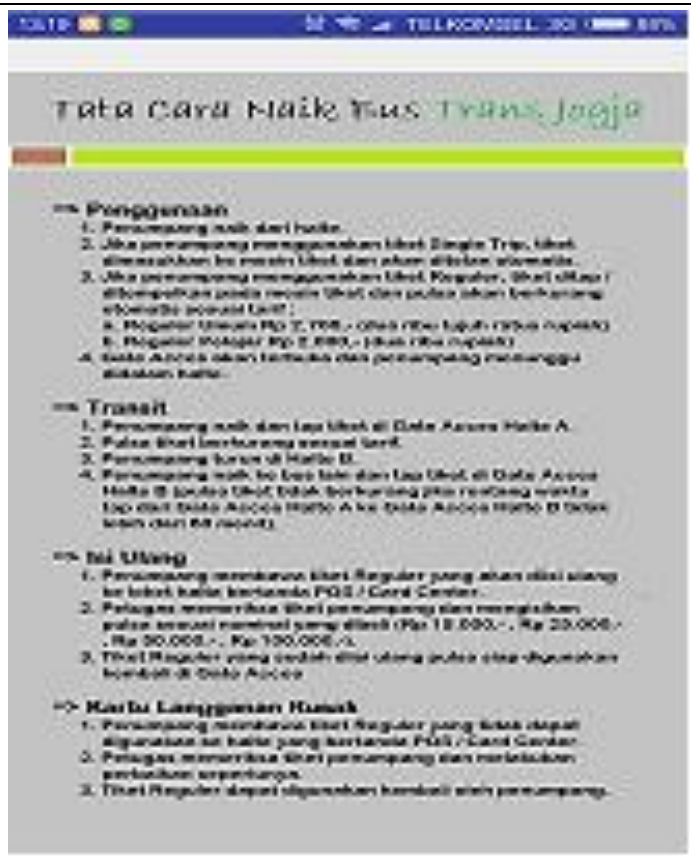

Gambar 8. Halaman Panduan Penumpang

\subsection{Pengujian}

Bagian ini akan memuat penjelasan mengenai pengujian terhadap perangkat lunak yang telah diimplementasikan. Metode pengujian yang dipakai adalah pengujian akurasi titik lokasi dan pengujian blackbox. Pengujian dilakukan bertujuan untuk mengetahui seberapa jauh berjalannya sebuah program atau keakuratan dari fungsi aplikasi. Selain itu, pengujian bertujuan mengevaluasi program dan perbaikan program untuk kedepannya.

\subsubsection{Pengujian Akurasi Titik Lokasi Pada Peta}

Pengujian akurasi dilakukan dengan cara menggunakan aplikasi untuk melakukan deteksi lokasi keberadaan Bus Trans Jogja yang sudah terpasang oleh alat GPS Tracker. Pengujian ini bertujuan untuk mengukur tingkat akurasi sistem dalam melakukan perkiraan lokasi. Berikut pengujian yang dilakukan di berbagai titik dengan beberapa skenario.

a) Skenario Pengujian Akurasi

Skenario pengujian yang dilakukan adalah dengan menentukan titik keberaadaan user dan titik keberadaan dari bus yang telah terpasang oleh alat GPS Tracker. Berikut merupakan skenario pengujian akurasi yang akan dijelaskan pada Tabel 1.

Tabel 1. Skenario Pengujian Akurasi

\begin{tabular}{cc}
\hline No. & Skenario \\
\hline 1. & User berada di Halte Fakultas Kedokteran UGM \\
2. & Bus berada di Magister Manajemen FE UGM \\
\hline
\end{tabular}

Skenario pengujian yang telah ditentukan dapat membantu untuk menentukan hasil yang diharapkan. Hasil titik akurasi yang didapatkan nantinya akan dibandingkan dengan akurasi yang sebenarnya pada google maps. Berikut pengujian yang telah dilakukan dengan skenario 1 dijelaskan pada Gambar 9.

Pada Gambar 9 dilakukan pengujian akurasi dengan skenario pengujian user berada di halte Fakultas Kedokteran UGM, sedangkan posisi bus berada di Magister Managemen UGM. Pengujian akurasi titik lokasi yang telah dilakukan nantinya dibandingkan dengan google maps. Perbandingan hasil akurasi titik lokasi dilakukan tujuannya untuk menilai keakuratan kinerja dari aplikasi Bus Trans Jogja. Hasil akurasi keberadaan bus tergantung bagaimana kinerja dari alat GPS Tracker apakah bisa memberikan informasi keberadaan realtime. Simcard yang terpasang pada alat GPS Tracker juga berperan besar karena apabila tidak terisi pulsa atau mengalami gangguan jaringan maka tidak dapat memberikan informasi keberadaan bus pada saat itu juga. 


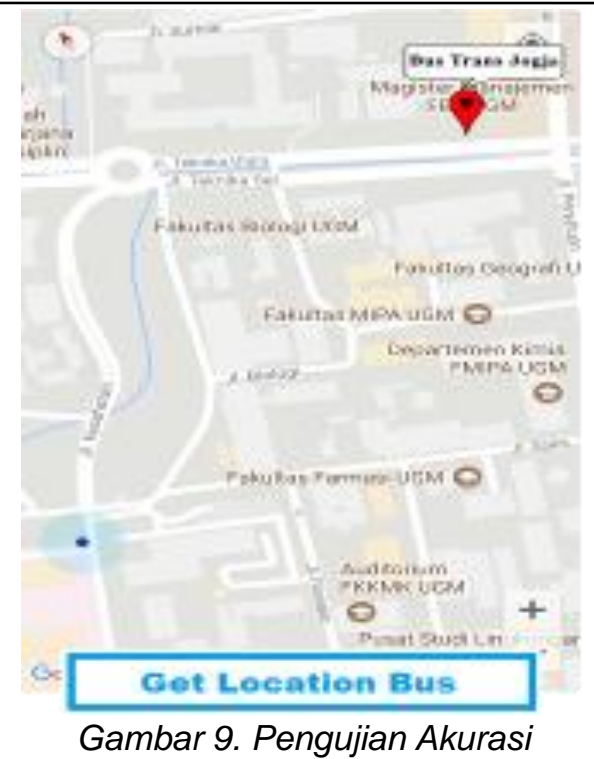

\subsubsection{Pengujian Blackbox}

Pengujian blackbox merupakan pengujian yang berfokus pada spesifikasi fungsionalitas dari suatu perangkat lunak. Hasil pengujian blackbox pada aplikasi ini dijelaskan di dalam Tabel 2.

Tabel 2. Pengujian Black box Aplikasi Bus Trans Jogja

\begin{tabular}{cccc}
\hline No. & Detail Pengujian & Hasil yang diharapkan & Hasil uji \\
\hline 1. & Menekan tombol bus location & Menampilkan posisi dari Bus Trans & {$[\sqrt{ }]$} \\
& Jogja & Sesuai \\
2. & Menekan tombol bus stop & Menampilkan lokasi halte Bus Trans & {$[\sqrt{ }]$} \\
& location & Jogja & Sesuai \\
3. & Menekan tombol maps & Menampilkan area Yogyakarta dan & {$[\sqrt{ }]$} \\
& Menekan tombol panduan & Menampilkan panduan bagi & Sesuai \\
4. & penumpang & penumpang & Sesuai \\
\hline
\end{tabular}

\section{Kesimpulan}

Dari hasil implementasi dan pengujian yang telah dilakukan pada bab sebelumnya dapat disimpulkan bahwa aplikasi yang dirancang dapat melihat posisi armada bus dan lokasi halte. Hal tersebut dapat dibuktikan pada hasil pengujian yang telah dilakukan.

\section{Referensi}

[1] "TRANS JOGJA Bus Umum yang Aman, Nyaman, dan Terjangkau." [Daring]. Tersedia pada: https://www.yogyes.com/id/yogyakarta-transportation/public/trans-jogja/. [Diakses: 11-Mar-2017].

[2] M. Fowler, UML distilled: a brief guide to the standard object modeling language, 3rd ed. Boston: Addison-Wesley, 2004.

[3] Raharjo, Novi Rosiana (2011) Pengaruh Kualitas Jasa Terhadap Citra Trans-Jogja.

[4] Singhal Manav dan Shukla Anupam, "Implementation of Location based Services in Android using GPS and Web Services," Int. Comput. Sci. Issues, vol. 9, no. 1, hlm. 2, Jan 2012.

[5] K. T. Martono dan O. D. Nurhayati, "Implementation of android based mobile Learning application as a flexible learning Media," Int J Comput Sci Issues IJCSI, vol. 11, no. 3, hlm. 168, 2014.

[6] S. Tao, V. Manolopoulos, S. Rodriguez, dan A. Rusu, "Real-Time Urban Traffic State Estimation with A-GPSMobile Phones as Probes," J. Transp. Technol., vol. 2, hlm. 22-31, 2012.

[7] Chasseur, Craig., Li, Y. dan Patel, Jm, "Enabling JSON Document Stores in Relational Systems," Sixt. Int. Workshop Web Databases, hlm. 2013. 
[8] Madcoms, Adobe Dreamweaver CS6 dengan pemrograman PHP dan MySQL. Yogyakarta: Penerbit Andi, 2013.

[9] Svennerberg Gabriel, Beginning Google Maps API 3. United States of America, 2010.

[10] El-Rabbany Ahmed, Introduction to GPS The Global Positioning System. 
REPOSITOR, Vol. 2, No. 2, Februari 2020: 155-164 